特 発 性側彎症の中枢性機能障害

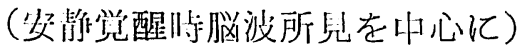

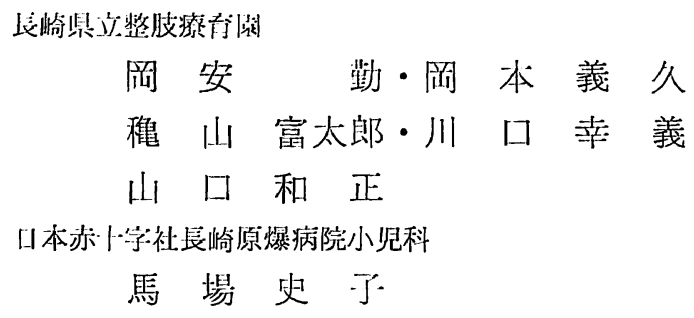

\title{
A Study of Cerebral Dysfunction by EEG in Patients with Idiopathic Scoliosis
}

by

Tutomu Okayasu, Yoshihisa Okamoto,

Tomitaro Akiyama, Yukiyoshi Kawaguchi and Kazumasa Yamaguchi

Nagasaki Prefectural Seishiryoikuen

Chikao Baba

Division of Pediatrics Japanese Red Cross Nagasaki Atomic Bomb Hospital

An electroencephalographic study was carried out on 54 children with idiopathic scoliosis, aged from 3 to 17 years and 20 normal development children aged from 7 to 16 years as controls. The results were as follows.

1) Abnormal EEG was found in 25.9 per cent of the scoliotic patients.

2) The main EEG abnormalities were high voltage slow wave burst, asymmetry and and spike potentials.

3) Abnormality of EEG of juvenile group (below 9 years) was 1.7 times higher than that of adoslecent group.

4) EEG abnormalities were correlated with the severity of the scoliosis.

目

的

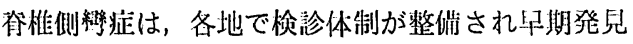
さ机るようになった之霄われる. しかし月常生活に何 ら不向由なく，まして本人には見えない背部の異常で あるため発胃が连机，装具療法のほぼ限界の角度で初 部する例も決して少くない，原因不明とさ机る特発性

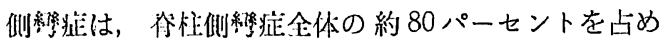

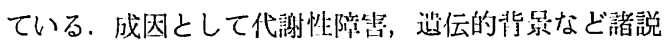
ある中で脸翰平衡中枢の罢常という山田，山本らの仮
説は非常に與味樑い，今回我々は特発性側彎症の中枢 性の異常を検索する目的で脳波検査を行なった.

\section{対象および方法}

当国外来通院中および入院中の特発性侧彎症患者 54 例に安静覚醒侍の脸波検祖を行なった. 痙戀の既往の ある者は除いた. 電極の配置は ten twenty electrode system に準じた. Control 群として正常児 及び 神経学的に特に異常のない疾患を 選んで 20 例に 同様の検査を行なった．判定は側樂等度を告げず小児 
神経科医に依頼した。 また約半数の症例には Romberg, Mann などの平衡機能検查および $\mathrm{N}$ 型バラン スボードテスト5)を行ない，合せて乘物酻いの存鮥に

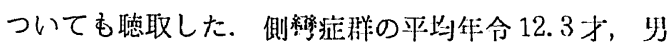
女比は 1 刘 5.8 で女が戍倒的に多かった. Control 呢 は11.5才，男女比はほぼ 1 刘 1 であった（衣1).

表 1 検 查 刘 象

\begin{tabular}{|c|c|c|c|}
\hline & 年令層 & 平的年令 & 男/女 \\
\hline 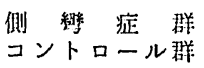 & $\begin{array}{l}3-17 \\
7-16\end{array}$ & $\begin{array}{l}12.3 \pm 3.0 \\
11.5 \pm 2.3\end{array}$ & $\begin{array}{r}8 / 46 \\
11 / 9\end{array}$ \\
\hline
\end{tabular}

結

果

脳波買常は側彎症 54 例中 14 例（25.9 パーセント） に対し, Control 群 5 パーセントで侧彎症の 4 分の 1

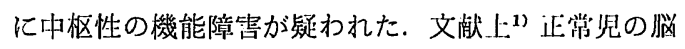
波異常出現頻度は 0 から 8.5 パーセントと報告されて おり，それと比べてあ高率であった．脳波異常を年令 別にみると，7才と17才を除けば各年令ほぼ均等に 異常が出現していた (Fig. 1).

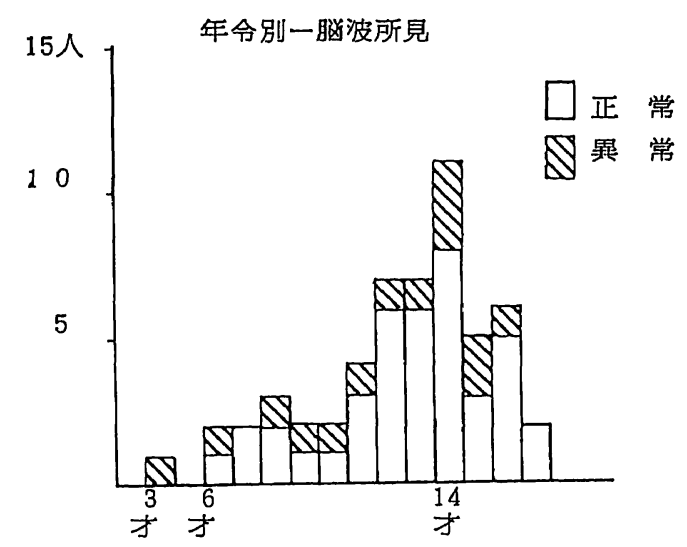

Fig. 1

また 10 才以上の 44 例と 9 才以下の 10 例とで罢常 脳波の出現頻度を比較すると 10 才以上 22.7 パーセン ト，9才以下 40 パーセントと思春期よりあむしろ低 年令層に高率であった. Cobb 角からの分類では, 初 診㭙の立位レントゲンから main curve，凹側を決 定し $10^{\circ} \sim 20^{\circ}, 21^{\circ} \sim 30^{\circ}, 31^{\circ} \sim 40^{\circ}, 41^{\circ}$ 以上の 4 段階 に分けた. 装具療法中のものが 39 例 72 パーセントを 占めていた，脳波異常は（Fig. 2) 右凸 $31^{\circ} \sim 40^{\circ}$ に 最む多く，また main curve の凸侧別の出現頻度は

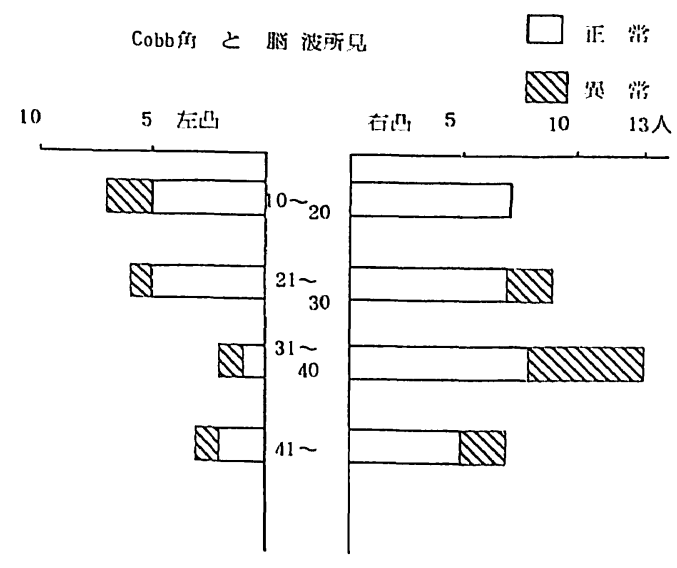

Fig. 2

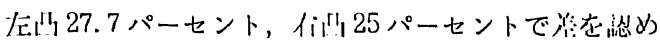
なかった. Control 排を Cobb 们 $0^{\circ}$ として侧彎の

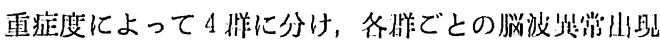

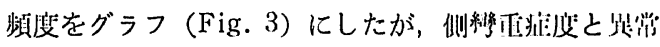

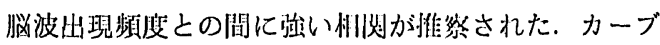
パターンによる分類では，54例们48例は恦性力ーブ と double カーブとで占めら扎ていた（Fig，1)，紧 常例の 64 パーセントは double カーブに蚛してい

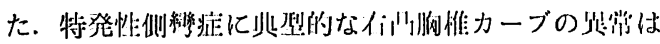
3 例のみであった。兴波罢常 14 例のうちわけは，高 振幅徐波非 6 例, 有:不疼 3 例, 料波 2 例, その他 3 例 であった.

\section{Cobb角と㮸波異常の出現䫖度}

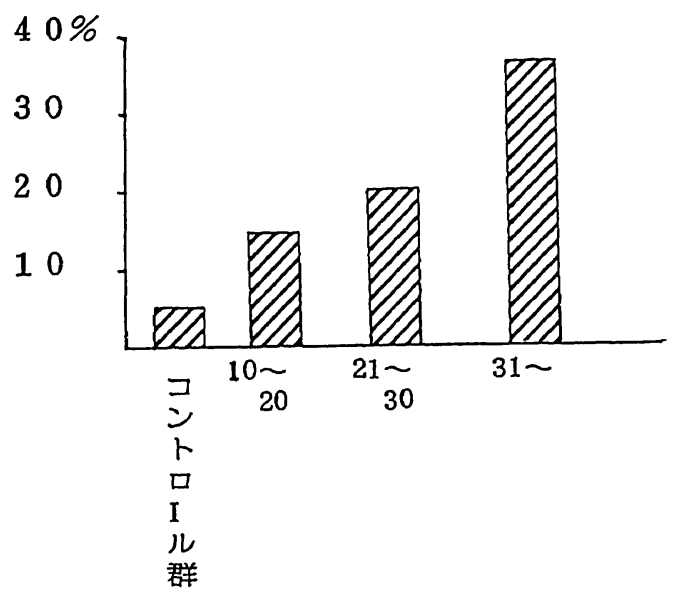

Fig. 3 


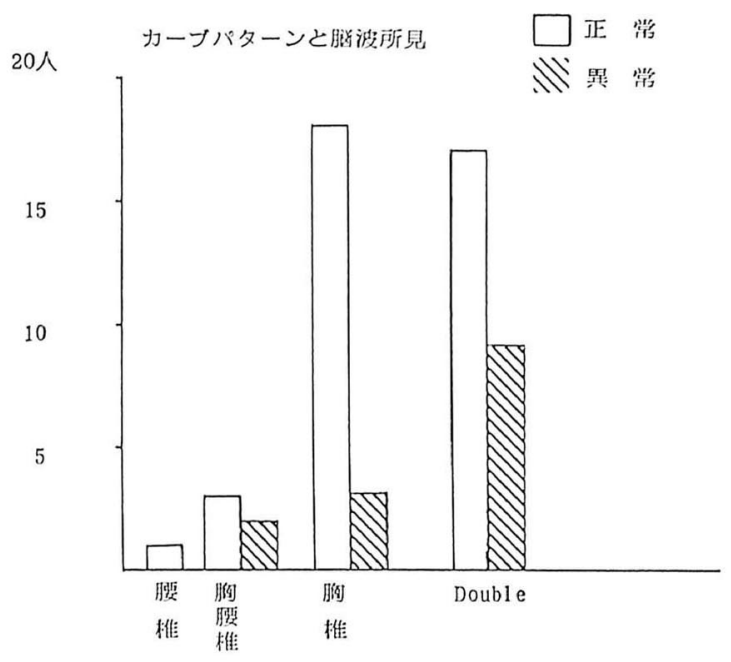

Fig. 4

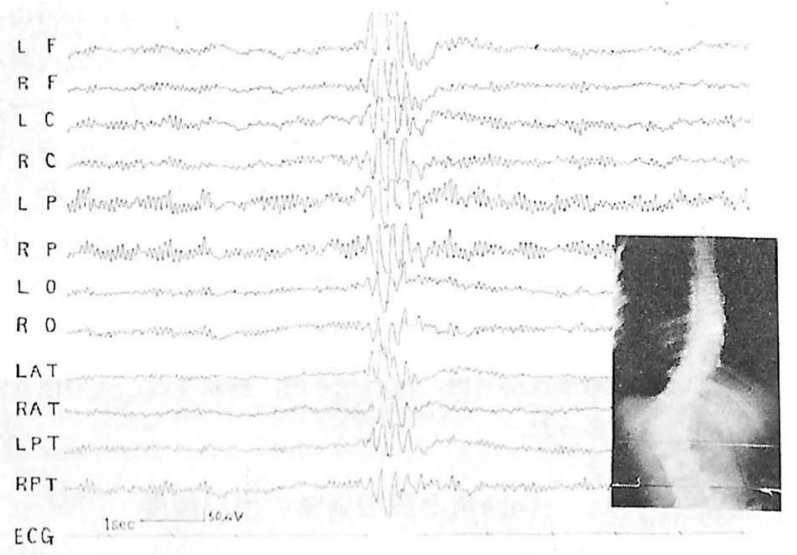

症 例 1

次に代表的症例を紹介する.

\section{症例}

症例 1 ) 12 才女 main curve 庄山 $25^{\circ}$ double 力 ーブ、平衡反応は正常で乘物酔いもなかった。脸波は frontal から parietal 中心で全誘導に及ぶ 4 から 5 ヘルッの高振幅徐波群 (High Voltage Slow wave burst）が出現している.

症例 2 ） 14 才女. 左凸 $39^{\circ}$ 胸腰椎カーブ. 乘物䤏 いが蓄明で，N犁 balance board $7.0 \mathrm{~cm}$ でのバラ ンス反応屯不良であった。兴波は右 postero-tem-

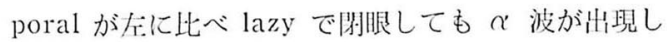
ていない.
症例 3 ） 14 才男. 右凹 $61^{\circ}$ 胸椎カーブ.

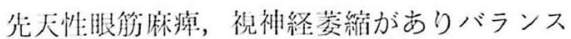
反応の発造不全も顕著であった，乘物酥いは なかった。脳波は右半球全体に陽性棘波 (positive spike) が出現している.

考察

金柱側彎症の成因という锶点から中枢神経

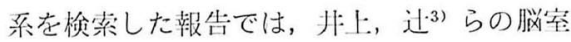
撮影, 脳波検查が最初と思われる。，その報告 では検查を行なった特発性側䋨症 4 例全例に 異常がみられたとしている．それは高振幅徐 波礁，䗲波などが主であった，次に特発性側 彎症の平衡機能障害に注目した山田・山本 8.9) らは「平衡機能の異常は側綡症の強度之 朋らかな相関関係があり，側綃症の進行の了 後を推察する手がかりになる.」と述べ，樑 部受容器と脸幹平衡中枢との feed back 機 情の存在を予言した，同じ研究グループの罒 村7) は脳幹中枢を選択的に破填することによ って侧綡症が発症してくることを奏騟的に 証明した。 また特発性側變症には乘物酔儿 (motion sickness) が高率にみられる事が 知られている。西いらは13才以下に高頻 度で，装具痖法などの治療によって症状改善 するものが 70 パーセントにものぼると報告 し, 車酕い発晛は腰部深部受容器と視器系に 関係が強い脳幹網様体との破綻によるものと 述べている. 我々の 54 例中乘物酔いについ て調查できた 28 例 のうち 15 例（53 パーセ ント）に乖物酔いを認めたが，脳波異常群と正常脳波 群とでは有意差はなかった，特発性側彎症の隠波とい う钼点からアプローチした研究は非常に少く, Lukeschitsch ${ }^{2)}$ Peterson ${ }^{6)}$ たちが報告しているものしか 見あたらなかった。前者は 115 例の特発性侧彎症に病 的所見が 50.5 パーセント認められたと報告した。 ま

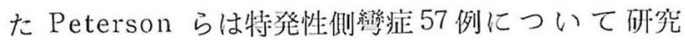
し, 安静覚醖時の異常波が Control 群に比べ有意に 高率に出現したと述べている. 今回の我々の研究で は, 症例の大部分を占的思期側彎症よりも乳幼㫛 期, 学童期に脳波異常が高率であった事が特徽の一つ である。さらに側彎の発症年令が 9 才以下であった 3 例を加えると乳幼児期・学童期発症の 13 例のうち脸 


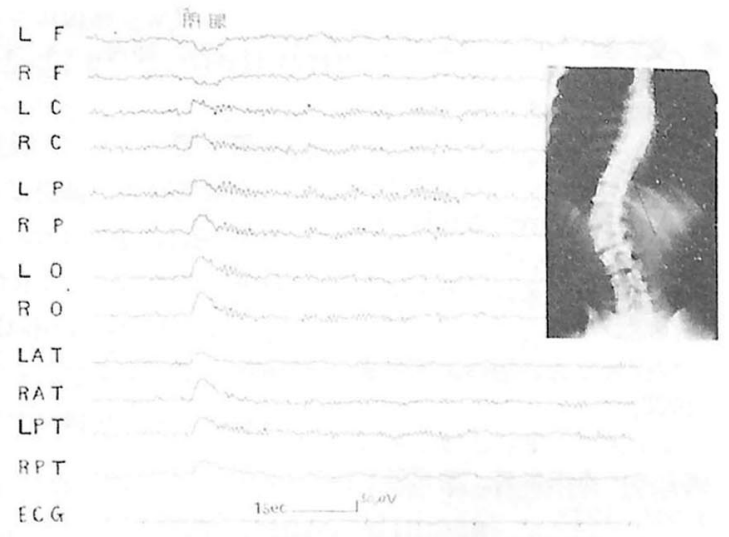

症 例 2

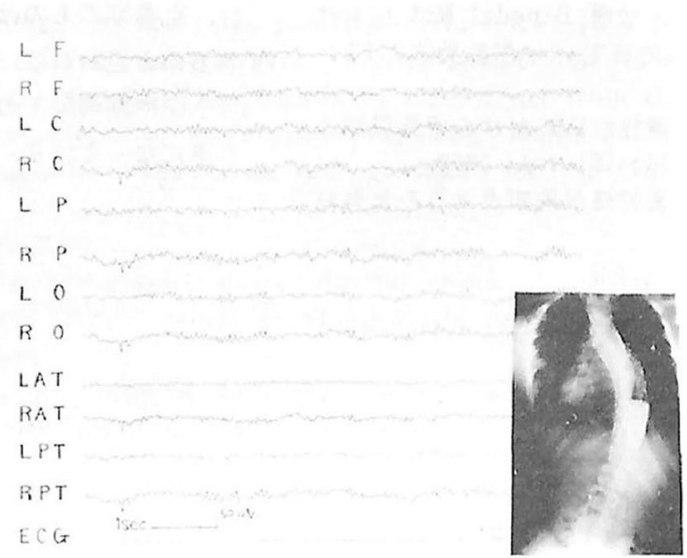

症 例 3

波異常 7 例（53 パーセント）となって 5 パーセントの 伦険率で有意差が認められた。中怄神経系の置常が非 な病因と考えるなら乳幼児期から発生しても何ら不思

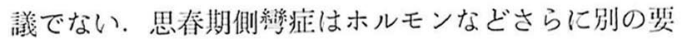
因が強く関与しているものと思われる。先に述べたよ うにCobb角が大きいものほど脳波異常が頻発する こと, カーブパターンでは double カーブが半分以 上を占める事などから，9才以下で発症し典型的仿い 胸椎カーブをとらず, 脳波異常を認める subgroup が考えられる。 そしてそれらは進行する可能性が高い と言える。 また異常波のうち高振幅徐波群は雨倒性に 全誘導にわたって出現し, 病紧が中心胹性つまり脳翰

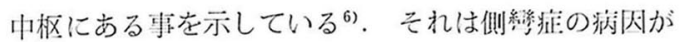
脳幹平衡中枢の買常であるという仮説を支持するもの

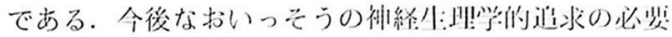
性在感じた.

$$
\text { ま と め }
$$

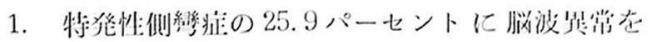

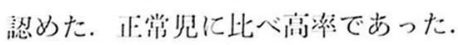

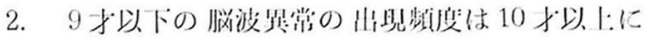
比べ 1.7 倍高加った。

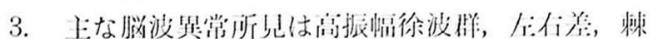
波であった。

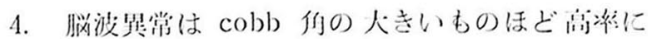
山胃した。 


\section{参考文 献}

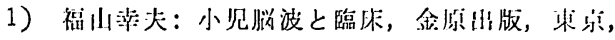
1980.

2) Lukeschitsch, G.: Zerebrale dysfunktion bei patienten mit idiopathischer Skoliose, Z. Orthop., 118: 372-375, 1980.

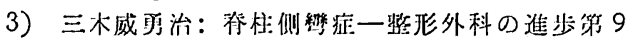
背一, 南江堂, 束京, 1965.

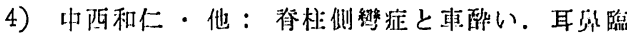
快, 71: 1045-1057, 1978.

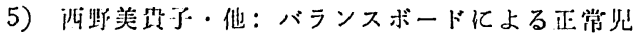
のバランス反応の部㑜とその臨圤応用，酱形外科 と災装外科，31：583-587，1983.

6) Petersen, Ingemar: Electroencephalographic Investigation of Patients with Adolescent Idiopathic Scoliosis, Acta orthop. scand., 50: 283-293, 1979.

7）回村人司：定位脳幹破塎 Bipedal Rat におけ

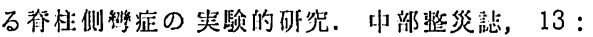
881-882, 1970.

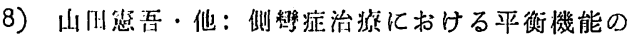

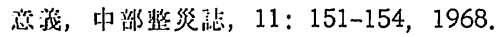

9）山且惩吾・他：平衡䘞経学的倠点よりみた脊柱

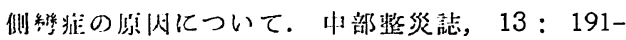
193, 1970.

質 問総合脊損センター 佐々木邦雄

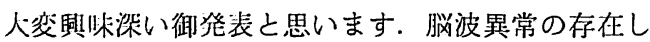
た症例は，juvenile でいわゆる典型的な adolescent type とは異なる印象をうけました. Entity としていわゆる idijathic と異る syndrome の様な あのを考えますが，先生の御考えを聞かせて下さい.

兴波買常の症例に対し何か薬物治療はあるのでしょ うか.

解 答亥崎県立整旼療育園 阙安勤

9才以ドで，発症する側彎症には中怕性障害が強く 関与しており，幻児期から発症していてあ不思議でな い. 思春期のむのはさらに別の factor が関与してい るむのと思われる.

小児神経科医との論議では特に治療を要しないとい う身になっている. 